\title{
ANALISIS DETERMINAN AUDIT REPORT LAG
}

\author{
Gilang Satrya Ramadhan \\ gilangsatrya@students.telkomuniversity.ac.id \\ Majidah \\ Eddi Budiono \\ Fakultas Ekonomi dan Bisnis, Universitas Telkom
}

diterima: 28/4/2017; direvisi: 30/1/2018; diterbitkan: 27/4/2018

\begin{abstract}
The purpose of this research is to determine the effect of leverage, size of company, audit quality and accounting result simultaneously or partially to the audit report lag. The type of this research is descriptive verificative. The number of manufacturing companies in the Indonesia Stock Exchange (BEI) over the period of 2011-2015 are 143 companies, then obtained a sample of 110 by purposive sampling. Analysis of data is carried out using multiple regression method. The results showed variable leverage, size company, audit quality and accounting result can explain audit report lag $33.3 \%$. Partial test results showed that leverage did not significantly affect, size company and accounting result have a significant negative effect and audit quality have a significant positive effect on audit report lag.
\end{abstract}

Keywords: leverage; size company; audit quality; accounting result; audit report lag

\begin{abstract}
Abstrak
Tujuan penelitian ini untuk mengetahui pengaruh variabel leverage, ukuran perusahaan, kualitas audit dan accounting result secara simultan maupun parsial terhadap variabel audit report lag. Penelitian ini bersifat deskriptif verifikatif, jumlah perusahaan manufaktur di BEI selama periode 2011-2015 sebanyak 143 perusahaan, kemudian didapatkan sampel sebanyak 110 dengan purposive sampling. Analisis data menggunakan regresi linear berganda. Hasil penelitian didapatkan bahwa leverage, ukuran perusahaan, kualitas audit, dan accounting result berpengaruh secara simultan dan dapat menjelaskan audit report lag sebesar 33,3\%. Hasil pengujian secara parsial didapatkan leverage tidak berpengaruh ukuran perusahaan dan accounting result berpengaruh signifikan negatif, serta kualitas audit berpengaruh signifikan positif terhadap audit report lag.
\end{abstract}

Kata Kunci : leverage; ukuran perusahaan; kualitas audit; accounting result; audit report lag 


\section{PENDAHULUAN}

Emiten wajib menyampaikan laporan keuangan tahunan tepat waktu, sehingga dapat dimanfaatkan dalam pengambilan keputusan. Ketepatan penyampaian laporan keuangan berhubungan dengan lamanya proses audit dimulai sejak tutup buku perusahaan dalam masa periode akuntansi hingga audit eksternal menandatangani hasil audit (audit report lag). Berikut ini peneliti sajikan grafik perusahaan yang tidak dan tepat dalam menyampaikan laporan keuangan pada tahun 2011 sampai 2015 di Bursa Efek Indonesia (Indonesian Stock Exchange).

Bursa Efek Indonesia

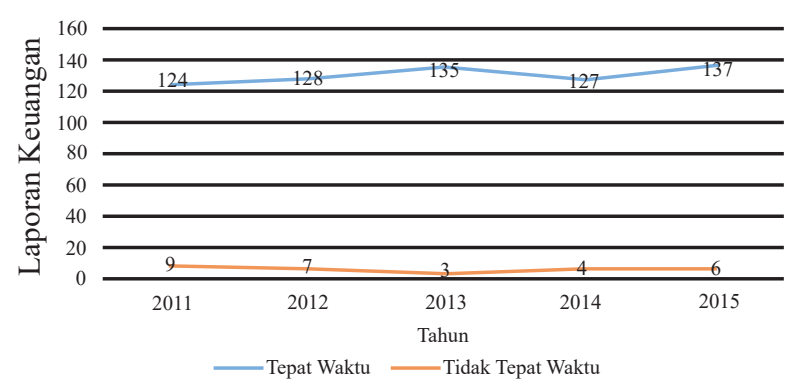

Gambar 1. Grafik Jumlah Penyampaian Laporan Keuangan

Gambar 1 menunjukkan terjadi penurunan perusahaan yang tidak tepat waktu menyampaikan laporan keuangan pada tahun 2011 hingga 2013, namun pada tahun 2014 dan 2015 mengalami kenaikan. Peraturan Otoritas Jasa Keuangan tentang publikasi laporan keuangan audited yang tertuang dalam pasal 7 mengenai kewajiban menyampaikan laporan tahunan paling lambat akhir bulan ketiga setelah tahun tutup buku berakhir. Sanksi administratif diberikan kepada perusahaan yang telat menyampaikan laporan keuangan. Selain sanksi administratif, perusahaan tersebut telah menghilangkan salah satu karakteristik laporan keuangan yaitu, relevan. Relevan merupakan ketepatan waktu penyampaian laporan keuangan sehingga informasi tersedia ketika pengguna membutuhkannya untuk pengambilan keputusan.

Keterlambatan publikasi laporan keuangan mengindikasikan terdapat masalah, seperti perusahaan mengalami kerugian yang merupakan bad news, sehingga memerlukan waktu yang lama dalam penyelesaian audit (Febrianty, 2011). Otoritas Jasa Keuangan memberikan rentang waktu penyelesaian audit atas laporan keuangan selama tiga bulan setelah tanggal tahun tutup buku perusahaan. Rentang waktu antara tanggal penutupan tahun buku hingga tanggal diselesaikan laporan tahunan yang telah di audit oleh auditor independen, rentan waktu ini biasa disebut Audit Report Lag (Iskandar dan Trisnawati, 2010). Semakin lama Audit Report Lag, maka akan berdampak pada publikasi laporan keuangan tahunan auditan per 31 Desember. Keterlambatan Audit Report Lag mengindikasikan adanya masalah pada laporan keuangan perusahaan. Beberapa faktor determinan yang kemungkinan mempengaruhi audit report lag adalah laverage, ukuran perusahaan, kualitas audit dan accounting result.

Menurut Febrianty (2011), bahwa rasio leverage merupakan kemampuan perusahaan dalam memenuhi liability-nya. Rasio leverage yang tinggi menunjukkan risiko keuangan perusahaan akan bertambah. Menurut penelitian sebelumnya, bahwa rasio leverage berpengaruh positif signifikan pada Audit Report Lag (Angruningrum \& Wirakusuma, 2013).

Perusahaan besar tidak memiliki alasan untuk menunda penerbitan laporan keuangan hasil audit, karena hal ini merupakan merupakan berita baik dan di sisi lain perusahaan yang listing di Bursa Efek Indonesia rata-rata perusahaan besar. Dalam penelitian ini, ukuran perusahaan diukur dengan log natural (ln) total aset karena mengacu kepada peraturan ketua BAPEPAM dan LK No Kep. 11/PM/1997 yang menyatakan bahwa ukuran perusahaan diukur dengan cara mempertimbangkan total aset. Penggunaan log natural dimaksudkan untuk mengurangi fluktuasi data yang berlebihan. Ukuran perusahaan berpengaruh negatif signifikan terhadap audit report lag (Megayanti \& Budiartha, 2016).

Kualitas dari sebuah proses audit merupakan hal yang sangat penting untuk menjamin bahwa laporan keuangan dapat digunakan sebagai dasar pengambilan keputusan yang akurat bagi pihak pengguna laporan keuangan (Sinaga, 2012 dalam Aisyah, Gunawan dan Purnamasari, 2016). Coram et al. (2008, dalam Hartadi 2012) bahwa kualitas auditor adalah seberapa besar kemungkinan seorang auditor menemukan adanya kesalahan material maupun tidak material dari laporan keuangan kemudian melaporkan dan mencantumkan dalam opini audit. Dalam penelitan ini, kualitas audit diukur dengan pendekatan Earning Surprise Benchmark. Menurut penelitian terdahulu, kualitas audit berpengaruh positif signifikan terhadap audit report lag (Dewi \& Yuyetta, 2014).

Hasil akuntansi atau yang sering disebut accounting result dalam informasi akuntansi, dapat memberikan good news maupun bad news kepada pengguna laporan keuangan. Perusahaan tidak akan menunda publikasi laporan keuangan ketika mendapatkan laba (good news), berbeda dengan ketika perusahaan mendapatkan rugi (bad news). Accounting result merupakan variabel terminology. Dalam penelitian Berthelot (2014), accounting result menggunakan Net Income sebagai indikatornya, dengan kata lain Net Income mencerminkan good news atau bad news pada perusahaan. Kemampuan perusahaan menghasilkan laba berhubungan dengan penyajian informasi kepada publik (Mulyono \& Majidah, 2015). 
Audit report lag merupakan rentang waktu penyelesaian pelaksanaan audit laporan tahunan, sejak tanggal tutup buku perusahaan sampai dengan tanggal yang tertera pada laporan auditan (Damayanti, Ekawati \& Sugara, 2013); Dewi \& Yuyetta (2014).

Kualitas audit dapat diartikan sebagai sikap auditor dalam melakasanakan tugas audit. Kualitas audit tercermin dari hasil laporan keuangan yang dapat diandalkan sesuai dengan standar yang berlaku umum (Generally Accepted Accounting Principles). (DeAngelo, 1981 dalam Ardiansyah, 2014). Kualitas audit dapat tercermin dalam sikap auditor dan dapat dilihat dalam standar umum yang mengharuskan auditor tidak boleh berpihak dan dapat menghadapi tekanan dari klien (DeAngelo, 1981 dalam Kurnia, et. al. 2014).

Pengukuran kualitas audit dalam penelitian ini menggunakan pendekatan earning surprise benchmark. Pendekatan ini dilaksanakan untuk meneliti apakah auditor mampu mengungkap dan melaporkan adanya praktik manajemen laba tersebut atau tidak. Pada penelitian Carey dan Simnett (2006), formula yang digunakan adalah earning/total assets. Earning surprise benchmark yang digunakan adalah antara $\mu-\sigma$ dan $\mu+\sigma$, dimana $\mu$ adalah rerata return on assets dan $\sigma$ adalah deviasinya. Kualitas audit diasumsikan buruk apabila: (a) Laba melebihi Earning Surprise Benchmark yaitu ketika ROA $>\mu+\sigma$ (Windows Dressing), artinya auditor memberi kesempatan membuat laporan keuangan menjadi bagus dan meningkatkan laba. (b) Rugi melebihi Earning Surprise Benchmark yaitu ketika ROA $<\mu-\sigma$ (Taking a Bath), artinya auditor memberi kesempatan membuat laporan keuangan menjadi buruk dan meningkatkan rugi.

Formulasi kualitas audit (MEET_BE) sebagai berikut: (a) MEET_BE $=1$ ketika memenuhi kriteria $\mu-\sigma<$ ROA $<\mu+\sigma$, menunjukkan proses audit yang dilaksanakan berkualitas. (b) MEET $\mathrm{BE}=0$ ketika $\mathrm{ROA}>\mu+\sigma$ (windows dressing) atau $\mathrm{ROA}<\mu-\sigma$ (taking a bath), sehingga menunjukkan bahwa proses audit yang dilaksanakan tidak berkualitas.

Leverage adalah ukuran atas dana yang disediakan pemilik dibandingkan dengan yang diberikan kreditur. Pembiayaan dengan hutang berpengaruh bagi perusahaan karena mempunyai beban tetap. Kegagalan membayar bunga menyebabkan kesulitan keuangan yang berakhir dengan kebangkrutan. Sebaliknya penggunaan hutang memberikan deduksi pajak yang menguntungkan bagi pemegang saham (Kamaludin, 2011:42). Penggunaan utang yang terlalu tinggi akan membahayakan karena perusahaan akan masuk dalam kategori extreme leverage (Fahmi, 2011:62 ; Darsono, 2005:54). Konsep tersebut diperkuat dengan pernyataan Alexandri (2008:196), bahwa total debt to equity ratio merupakan rasio yang digunakan untuk menilai banyaknya hutang yang digunakan perusahaan.
Ukuran perusahaan dapat dilihat dari total nilai asset, total penjualan, dan jumlah tenaga kerja (Tiono dan Yulius, 2012 dalam Megayanti, 2016). Sesuai dengan lampiran keputusan ketua BAPEPAM dan LK No Kep. 11/PM/1997 bahwa, ukuran perusahaan kecil diukur dengan cara melihat total aset adalah $\mathrm{Rp}$ 100.000.000.000,- dan syarat ukuran perusahaan besar memiliki total aset sama dengan atau lebih besar dari Rp 100.000.000.000,-. Ukuran perusahaan dalam penelitian ini menggunakan log natural (ln) total assets.

Accounting result atau yang sering disebut hasil akuntansi bisa berupa laba atau rugi. Dalam penelitian Berthelot (2014), accounting result menggunakan Net Income sebagai indikatornya. Accounting result dapat memberikan good news bahkan bad news bagi investor. Good news yang berarti perusahaan mendapatkan keuntungan akan mendorong pihak perusahaan untuk segera mempublikasikan laporan keuangannya. Pernyataan tersebut didukung oleh Carslaw dan Kaplan dalam penelitian Mulyono \& Majidah (2015) membuktikan bahwa, kemampuan perusahaan menghasilkan laba berhubungan dengan penyajian informasi tersebut kepada publik.

Accounting result dalam penelitian ini menggunakan net income sebagai indikatornya. Variabel ini merupakan variabel dummy, sehingga jika perusahaan menghasilkan laba pada tahun berjalan maka diberikan nilai 1 . Jika perusahaan mendapatkan kerugian pada tahun berjalan maka diberikan nilai 0 .

\section{METODE}

Populasi penelitian ini adalah laporan keuangan perusahaan manufaktur yang terdaftar di Bursa Efek Indonesia tahun 2011-2015. Teknik sampel menggunakan purposive sampling dan analisis menggunakan statistik deskriptif dan regresi linier berganda.

\section{HASIL}

Statistik deskriptif bersifat rasio ditunjukkan pada Tabel 1.

Tabel 1. Statistik Deskriptif Variabel Audit Report Lag, Leverage dan Ukuran Perusahaan

\begin{tabular}{lccccc}
\hline & $\mathrm{N}$ & Minimum & Maximum & Mean & $\begin{array}{c}\text { Std. } \\
\text { Deviation }\end{array}$ \\
\hline $\begin{array}{l}\text { Audit } \\
\text { Report Lag }\end{array}$ & 250 & 70.0000 & 91.0000 & 81.024000 & 3.9412635 \\
$\begin{array}{l}\text { Leverage } \\
\text { Ukuran }\end{array}$ & 250 & -30.5981 & 70.8315 & 1.324149 & 5.6391534 \\
$\begin{array}{l}\text { Perusahaan } \\
\text { Valid } N\end{array}$ & 250 & 22.3286 & 32.1510 & 28.120953 & 1.5833980 \\
\begin{tabular}{l} 
(listwise) \\
\hline
\end{tabular} & 250 & & & & \\
\hline
\end{tabular}

Sumber : Output SPSS 22 
Hasil analisis statistik adalah sebagai berikut: (a) Nilai rata-rata audit report lag lebih besar dari pada standard deviasi mengindikasikan bahwa besarnya simpangan data dan kecilnya fluktuasi data. Rata-rata tersebut mencerminkan bahwa perusahaan memiliki audit report lag berkisar 81 hari. Nilai maksimalnya sebesar 91 hari dan minimumnya sebesar 70 hari. (b) Nilai rata-rata leverage lebih kecil dari pada standard deviasi mengindikasikan bahwa kecilnya simpangan data dan besarnya fluktuasi data. Nilai maksimalnya sebesar 70.8315 dan minimumnya sebesar -30.5981. (c) Nilai rata-rata leverage lebih besar dari pada standard deviasi mengindikasikan bahwa besarnya simpangan data dan kecilnya fluktuasi data. Nilai maksimalnya sebesar 32.1510 dan minimumnya sebesar 22.3286.

Statistik deskriptif bersifat nominal ditunjukkan pada Tabel 2 dan 3.

Tabel 2. Statistik Deskriptif Kualitas Audit

\begin{tabular}{|c|c|c|c|c|c|}
\hline & & Frequency & Percent & $\begin{array}{c}\text { Valid } \\
\text { Percent }\end{array}$ & $\begin{array}{c}\text { Cumulative } \\
\text { Percent }\end{array}$ \\
\hline $\begin{array}{l}\text { Non- } \\
\text { Kualitas } \\
\text { Audit: }\end{array}$ & & & & & \\
\hline $\begin{array}{l}\text { Windows } \\
\text { Dressing }\end{array}$ & .0000 & 12 & 4.8 & 4.8 & 32.4 \\
\hline $\begin{array}{l}\text { Taking a } \\
\text { Bath }\end{array}$ & .0000 & 25 & 10 & 10 & 67.6 \\
\hline $\begin{array}{l}\text { Kualitas } \\
\text { Audit }\end{array}$ & 1.0000 & 213 & 85.2 & 85.2 & 100.0 \\
\hline & Total & 250 & 100.0 & 100.0 & \\
\hline
\end{tabular}

Sumber: Output SPSS 22

Tabel 3. Statistik Deskriptif Accounting Result

\begin{tabular}{cccccc}
\hline & & Frequency & Percent & $\begin{array}{c}\text { Valid } \\
\text { Percent }\end{array}$ & $\begin{array}{c}\text { Cumulative } \\
\text { Percent }\end{array}$ \\
\hline Valid & .0000 & 47 & 18.8 & 18.8 & 18.8 \\
& 1.0000 & 203 & 81.2 & 81.2 & 100.0 \\
\cline { 2 - 6 } & Total & 250 & 100.0 & 100.0 & \\
\hline
\end{tabular}

Sumber : Output SPSS 22

Tabel 2 menunjukkan bahwa mayoritas perusahaan yang memiliki audit yang berkualitas yang berada dalam industri manufaktur dengan 213 data dari total 250 data. $(1=$ apabila perusahaan tidak terindikasi windows dressing dan taking a bath, $0=$ apabila perusahaan terindikasi windows dressing dan taking a bath). Tabel 3 menunjukkan bahwa mayoritas perusahaan manufaktur mendapatkan laba pada tahun berjalan dengan 203 data dari total 250 data. $(1=$ apabila perusahaan mendapatkan laba, $0=$ apabila perusahaan mendapatkan rugi).

Hasil uji asumsi klasik menunjukkan data berdistribusi normal, tidak terdapat multikolinearitas dan heteroskedastisitas. Pengaruh simultan dapat dijelaskan pada Tabel 4 tentang koefisien determinasi dan Tabel 5 tentang uji F simultan.
Tabel 4. Koefisien Determinasi $\left(\mathrm{R}^{2}\right)$

\begin{tabular}{ccccc}
\hline Model & $\mathrm{R}$ & $R$ Square & $\begin{array}{c}\text { Adjusted } R \\
\text { Square }\end{array}$ & $\begin{array}{c}\text { Std. Error of } \\
\text { the Estimate }\end{array}$ \\
\hline 1 & $.577^{\mathrm{a}}$ & .333 & .322 & 3.2451599 \\
\hline
\end{tabular}

Sumber : Output SPSS 22

Tabel 5. Hasil Pengujian Signifikan Simultan (Uji Statistik F)

\begin{tabular}{|c|c|c|c|c|c|c|}
\hline \multicolumn{2}{|c|}{ Model } & \multirow{2}{*}{$\begin{array}{c}\begin{array}{c}\text { Sum of } \\
\text { Squares }\end{array} \\
1287.746\end{array}$} & \multirow{2}{*}{$\frac{\mathrm{df}}{4}$} & \multirow{2}{*}{$\begin{array}{c}\text { Mean } \\
\text { Square }\end{array}$} & \multirow{2}{*}{$\frac{F}{30.570}$} & \multirow{2}{*}{$\frac{\text { Sig. }}{.000 b}$} \\
\hline 1 & Regression & & & & & \\
\hline & Residual & 2580.110 & 245 & 10.531 & & \\
\hline & Total & 3867.856 & 249 & & & \\
\hline
\end{tabular}

Sumber : Output SPSS 22

Tabel 4 dan 5 menunjukkan bahwa diperoleh nilai koefisien determinasi R-Square sebesar 0.333 atau $33.3 \%$ dengan tingkat signifikansi sebesar 0.000 yang lebih rendah dari tingkat signifikansi $\alpha=5 \%$. Dengan demikian, secara simultan leverage $\left(\mathrm{X}_{1}\right)$, ukuran perusahaan $\left(\mathrm{X}_{2}\right)$, kualitas audit $\left(\mathrm{X}_{3}\right)$ dan accounting result $\left(\mathrm{X}_{4}\right)$ berpengaruh secara signifikan terhadap audit report lag (Y). Variabel dependen yang dapat dijelaskan oleh variabel independen adalah sebesar $33.3 \%$.

Pengaruh parsial dapat dijelaskan pada Tabel 6 tentang koefisien regresi.

Tabel 6. Hasil Pengujian Analisis Regresi Linier

\begin{tabular}{|c|c|c|c|c|}
\hline \multirow{2}{*}{\multicolumn{2}{|c|}{ Model }} & \multicolumn{2}{|c|}{ Unstandardized Coefficients } & \multirow[b]{2}{*}{ Sig. } \\
\hline & & $\mathrm{B}$ & Std. Error & \\
\hline \multirow[t]{5}{*}{1} & (Constant) & 109.505 & 3.715 & .000 \\
\hline & Leverage & .065 & .037 & .079 \\
\hline & Ukuran Perusahaan & -.964 & .130 & .000 \\
\hline & Kualitas Audit & 2.339 & .642 & .000 \\
\hline & Accounting Result & -4.368 & .561 & .000 \\
\hline
\end{tabular}

Sumber : Output SPSS 22

Berdasarkan Tabel 6 dapat dibentuk persamaan regresi linier berganda sebagai berikut:

$Y=109.505+0.065 X_{1}-0.964 X_{2}+2.339 X_{3}-4.368 X_{4}$

Berdasarkan regresi diinterpretasikan: (a) Konstanta $(\alpha)$ sebesar 109.505 dengan tingkat signifikansi sebesar 0.000 berarti jika leverage $\left(\mathrm{X}_{1}\right)$, ukuran perusahaan $\left(\mathrm{X}_{2}\right)$, kualitas audit $\left(\mathrm{X}_{3}\right)$ dan accounting result $\left(\mathrm{X}_{4}\right)$ dianggap bernilai 0 atau konstan, maka nilai audit report lag (Y) tetap sebesar 109.505. (b) Leverage $\left(\beta_{1}\right)$ sebesar 0.065 dengan tingkat signifikansi sebesar 0.79 menunjukkan bahwa leverage tidak berpengaruh terhadap audit report lag. (c) Ukuran perusahaan $\left(\beta_{2}\right)$ sebesar -0.964 tingkat signifikansi 0.000 menunjukkan ukuran perusahaan berpengaruh negatif signifikan terhadap audit report lag. (d) Kualitas audit $\left(\beta_{3}\right)$ sebesar 2.339 tingkat signifikansi 0.000 menunjukkan kualitas audit berpengaruh positif signifikan terhadap audit report lag. (e) Accounting 
result $\left(\beta_{4}\right)$ sebesar -4.368 tingkat signifikansi 0.000 menunjukkan accounting result berpengaruh negatif signifikan terhadap audit report lag.

\section{PEMBAHASAN}

Hasil penelitian menunjukkan, leverage tidak berpengaruh terhadap audit report lag, disebabkan leverage memiliki sebaran data yang tinggi artinya jarak antara variabel satu dengan yang lainnya sangat tinggi. Terlihat pada Tabel 1 bahwa nilai minimum variabel leverage adalah -30.5981 sedangkan nilai maksimum adalah 70.8315 , sehingga variabel leverage tidak berpengaruh terhadap audit report lag. Hasil ini tidak didukung oleh hasil penelitian Angruningrum \& Wirakusuma (2013) yang menyatakan leverage berpengaruh positif terhadap audit report lag.

Ukuran perusahaan berpengaruh signifikan dan memiliki koefisien regresi negatif yang berarti semakin besar ukuran perusahaan, berdampak pada menurunnya audit report lag. Perusahaan manufaktur besar tentunya memiliki sistem pengendalian yang baik dan kompleks serta standar operasional prosedur yang lengkap, sehingga memerlukan proses audit yang lebih singkat. Selain itu pemilik akan menjaga reputasi perusahaannya dengan memberikan pengawasan ketat sehingga mempersingkat proses audit dan memperkecil kemungkinan terjadinya keterlambatan publikasi. Hasil penelitian ini didukung oleh Ariyani \& Budiartha (2014) yang menyatakan bahwa ukuran perusahaan berpengaruh negatif secara signifikan terhadap audit report lag.

Kualitas audit berpengaruh signifikan dan memiliki koefisien regresi positif terhadap audit report lag yang berarti semakin baik kualitas audit, maka akan berdampak pada meningkatnya audit report lag dengan pengaruh yang signifikan. Sebaliknya, semakin buruk kualitas audit, maka akan berdampak pada menurunnya audit report lag dengan pengaruh yang signifikan.

Meningkatnya kualitas audit mencerminkan bahwa perusahaan tidak terindikasi praktik manajemen window dressing serta taking a bath yang berarti hal tersebut membuat auditor harus lebih berhati-hati ketika melaksanakan proses audit untuk mendeteksi apakah perusahaan tersebut terindikasi praktik manajemen tersebut atau tidak, karena praktik manajemen tersebut merupakan usaha yang dilakukan oleh perusahaan dalam penghindaran pajak yang tinggi (taking a bath) dan kepentingan manajemen dalam mendapatkan komisi (windows dressing). Kualitas audit yang baik dapat dilihat dari seberapa bisa auditor dalam menemukan temuan pelanggaran dan mengungkapnya. Pemenuhan standar dan proses penemuan pelanggaran indikasi praktik manajemen tersebut akan memakan waktu sehingga berdampak pada lamanya proses audit yang dijalankan. Hasil penelitian ini didukung oleh Dewi \& Yuyetta (2014) yang menyatakan bahwa kualitas audit berpengaruh secara positif dan signifikan terhadap audit report lag.

Accounting result berpengaruh signifikan dan memiliki koefisien regresi negatif yang berarti semakin tinggi nilai accounting result, maka akan berdampak pada menurunnya audit report lag dengan pengaruh yang signifikan. Semakin rendah nilai accounting result, maka akan berdampak pada meningkatnya audit report lag dengan pengaruh yang signifikan.

Tingginya nilai accounting result mencerminkan bahwa perusahaan mendapatkan laba. Perusahaan yang memperoleh laba merupakan good news yang mencerminkan baiknya kinerja suatu perusahaan, sehingga pihak perusahaan tidak akan menunda penerbitan laporan keuangan sehingga akan mempersingkat audit report lag.

\section{KESIMPULAN}

Kesimpulan yang diperoleh bahwa secara parsial leverage tidak berpegaruh, ukuran perusahaan berpengaruh negatif signifikan, kualitas audit berpengaruh positif signifikan dan accouting result berpengaruh negatif signifikan terhadap audit report lag.

Secara teoritis disarankan untuk meneliti variabel lain yang masih berkaitan dengan audit report lag, sampel penelitian yang lebih banyak, serta periode penelitian rentang waktunya ditambah dan variabel kualitas audit menggunakan pendekatan Earning Surprise Benchmark agar dapat mengklasifikasikan variabel menjadi tiga kategori yaitu kualitas baik, taking a bath dan windows dressing.

Saran secara praktis bagi manajemen perusahaan manufaktur, sebaiknya meningkatkan pengendalian dan memperbarui standar operasional prosedur yang lebih ketat dan lengkap. Bagi auditor eksternal sebaiknya dilaksanakan proses audit yang lebih rinci dan ketat.

\section{DAFTAR PUSTAKA}

Aisyah, F., Gunawan, H. and Purnamasari, P., 2016. Pengaruh Audit Rotation dan Audit Tenure terhadap Kualitas Audit dengan Fee Audit sebagai Variabel Pemoderasi (Studi pada Manufaktur yang Terdaftar di Bei Tahun 2012-2014).

Angruningrum, S., \& Wirakusuma, M. G. 2013. Pengaruh Profitabilitas, Leverage, Kompleksitas Operasi, Reputasi KAP dan Komite Audit Pada Audit Delay. E-Jurnal Akuntansi Universitas Udayana, 5(2), 251-270.

Arens et al. 2012. Jasa Audit dan Assurance. (Buku I). Jakarta: Salemba Empat.

Berthelot, S. 2014. Corporate governance mechanisms, accounting results and stock valuation in Canada. International Journal of Managerial Finance, 10(4), 494-510. https://doi. org/10.1108/17439131211261251 
Carey, P. and Simnett, R., 2006. Audit partner tenure and audit quality. The accounting review, 81(3), pp.653-676.

Damayanti, E. R., Ekawati, R. K., \& Sugara, K. 2013. Pengaruh Kualitas Audit, Ukuran Perusahaan Dan Opini Auditor Terhadap Lamanya Audit Delay Pada Perusahaan Yang Terdaftar Di Bei. Jurnal Akuntansi, (x), 1-11.

Darsono, dan Ashari. 2005. Pedoman Praktis Memahami Laporan Keuangan. Yogyakarta: Andi Offset.

Dewi, S. G. P., \& Yuyetta, E. N. A. 2014. Pengaruh Kualitas Audit Dan Tenure Audit Terhadap Audit Repot Lag ( Arl ) Dengan Spesialisasi Auditor Industri Sebagai Variabel Moderasi ( Studi Empiris pada Perusahaan - Perusahaan Manufaktur yang Listing di BEI tahun 2010 - 2012 ). Diponegoro Journal of Accounting, 3, 1-11. Retrieved from http://ejournal-s1.undip.ac.id/index.php/accounting

Fahmi, Irham. 2011. Analisis Kinerja Keuangan. Bandung: CV. Alfabeta.

Febrianty. 2011. Faktor-Faktor Yang Berpengaruh Terhadap Audit Delay Perusahaan Sektor Perdagangan Yang. Jurnal Ekonomi Dan Informasi Akuntansi, 1(3), 294-320.
Hartadi, B., 2012. Pengaruh fee audit, rotasi KAP, dan reputasi auditor terhadap kualitas audit di Bursa Efek Indonesia. EKUITAS (Jurnal Ekonomi dan Keuangan), 16(1), pp.84-104.

Kamaluddin. 2011. Manajemen Keuangan "Konsep Dasar dan Penerapannya". Bandung: CV. Mandar Maju.

Kurnia, W., Khomsiyah, dan Sofie. 2014. Pengaruh Kompetensi, Independensi, Tekanan Waktu, dan Etika Auditor terhadap Kualitas Audit. E-Journal Akuntansi Fakultas Ekonomi Universitas Trisakti, 1(2), pp.49-67.

Megayanti, P. 2016. Pengaruh Pergantian Auditor, Ukuran Perusahaan, Laba Rugi Dan Jenis Perusahaan Pada Audit Report Lag. E-Jurnal Akuntansi Universitas Udayana, 14, 1481-1509. Mulyono, A., \& Majidah. 2015. Auditor Switching : Perbedaan Aktivitas Dan Pangsa Pasar Auditor Setelah Corporate Takeovers Auditor Switching : Differences Of Activities And Auditor 'S. Jurnal Akuntansi.

www.kemenperin.go.id/[2 September 2016] www.idx.co.id/[6 September 2016] www.sahamok.com/[6 September 2016] www.ojk.go.id/[8 September 2016] 